\title{
THE INFLUENCE OF KINEMATIC VISCOSITY OF A LUBRICANT ON BROADBAND ROLLING BEARING VIBRATIONS IN AMPLITUDE TERMS
}

\author{
Bartosz JAKUBEK, Roman BARCZEWSKI \\ Poznan University of Technology, Faculty of Mechanical Engineering and Management, Poznan, Poland, \\ bartosz.jakubek@put.poznan.pl, roman.barczewski@put.poznan.pl
}

\begin{abstract}
Long and trouble-free operation of rolling bearings is largely dependent on their lubrication. Depending on their properties, lubricants reduce the levels of vibration and noise generated by a running bearing to varying degrees. Such an influence of the lubricant is usually desirable during operation. On the other hand, from the point of view of post-production diagnostics, which uses vibroacoustic (VA) signals to evaluate the quality of bearings, lubricants can lead to unwanted masking of damage and manufacturing defects. This is due to a decrease in amplitude and/or a change in the spectral composition of the vibrations. Studies on the influence of lubricants on bearing vibrations were carried out on a set of 10 new tapered roller bearings using 12 oils of different kinematic viscosity. On the basis of the test results, the influence of oil viscosity on the level of vibrations generated by bearings and the nature of this relationship were determined. The sensitivity of selected measures of acceleration of bearing vibrations to changes in viscosity of the lubricant used was determined in this paper. On this basis, the premises concerning the criteria for selection of a lubricant for the purpose of post-production diagnostics of rolling bearings were specified. Appropriate lubricant parameters have been defined to guarantee the stability of the rolling bearing testing process and to reduce the masking of manufacturing defects in the VA signal.
\end{abstract}

Keywords: rolling bearings vibration, lubrication, post-production testing

\section{WPŁYW LEPKOŚCI KINEMATYCZNEJ ŚRODKA SMARNEGO NA SZEROKOPASMOWE DRGANIA ŁOŻYSK TOCZNYCH W UJĘCIU AMPLITUDOWYM}

\begin{abstract}
Długa i bezawaryjna praca łożysk tocznych w dużej mierze uzależniona jest od ich smarowania. Środki smarne, w zależności od swoich właściwości, w różnym stopniu obniżają poziomy drgań i hałasu generowanego przez pracujące łożysko. Takie oddziaływanie środka smarnego jest zwykle pożądana na etapie eksploatacji. Natomiast z punktu widzenia diagnostyki kontrolnej (poprodukcyjnej), wykorzystującej sygnały wibroakustyczne (WA) do oceny jakości łożysk, substancje smarujące mogą prowadzić do niepożądanego maskowania uszkodzeń i wad produkcyjnych. Wynika to $z$ obniżenia amplitud i/lub zmiany składu widmowego drgań. Badania wpływu środka smarnego na drgania łożysk przeprowadzono na zestawie 10 nowych łożysk stożkowych z zastosowaniem 12 olejów o różnej lepkości kinematycznej. Na podstawie wyników testów określono wpływ lepkości oleju na poziom drgań generowanych przez łożyska oraz określono charakter tej zależności. W pracy określono wrażliwość wybranych miar przyspieszeń drgań łożysk na zmiany lepkości stosowanego środka smarnego. Na tej podstawie sprecyzowano przesłanki dotyczące kryteriów doboru środka smarnego na potrzeby diagnostyki kontrolnej (poprodukcyjnej) łożysk tocznych. Określono parametry środka smarnego gwarantujące stabilność procesu testowania łożysk tocznych i przyczyniające się do ograniczenia maskowania wad produkcyjnych w sygnale WA.
\end{abstract}

Słowa kluczowe: drgania łożysk tocznych, smarowanie, testowanie poprodukcyjne

\section{INTRODUCTION}

The primary function of the lubricant in a rolling bearing is to produce a thin film separating the metal rolling elements and raceways, which results in a reduction in friction [1,2]. Lubrication of the bearings leads to improved tribological properties and increases the operational reliability of the bearings $[3,4]$. It is estimated that about $1 / 3$ of premature bearing damage is caused by the use of a wrong type of grease or by its insufficient quantity $[5,6]$. Generally, the denser/more viscous the lubricant used, the lower the vibration and noise levels of the bearing [7]. On the other hand, the use of high viscosity lubricants in most cases results in masking defects/damage, which can be reflected in the vibration signal emitted by the bearing. Considering that the vast majority of rolling bearing diagnosis methods are based on vibration and noise measurements and analyses [8, 9], the type of lubricant used is significant in terms of defect/damage detection efficiency. Therefore, the selection of an appropriate lubricant will be important from the point of view of the methods of operational diagnostics and, in particular, 
vibroacoustic methods of post-production quality control of new bearings. According to ISO 15242 [10] it is recommended to use oils with viscosity $10-100 \mathrm{~mm}^{2} / \mathrm{s}$ for post-production tests of new bearings. However, selection of a specific type of lubricant and determination of the criterion values of the vibration signal parameters used to assess the quality of bearings have been left to the manufacturer. He should take into account the type, size and purpose of the bearing when selecting the lubricant.

Many of research results presented in the literature concerns thermal and/or friction phenomena occurring in rolling bearings. It has been shown that an increase in amount or the viscosity of the lubricant results in a higher operating temperature of the bearing $[11,12]$ which is strived asymptotically $[13,14]$.

On the other hand, other authors state that the use of lubricants with higher viscosity generally slows down the bearing's wear process $[2,15,16]$. Only a few papers report the results of research related to the effect of the kinematic viscosity of the lubricant on bearing vibrations. Jamadar and Vakharia observed a decrease of amplitudes of spectral components related to local defects of the bearings along with an increase in viscosity of the lubricant [6]. While Serrato, Maru and Padovese have shown that changes in lubricant viscosity can be detected through vibration monitoring [17].

However, we do not find detailed information on the influence of lubricant parameters on the detection/identification of manufacturing defects. Such knowledge is indispensable for development of effective post-production bearing diagnostics methods based on VA methods.

\section{RESEACH METODOLOGY}

The aim of the study in the first approach was to determine the influence of oil (lubricant) viscosity on the level of bearing vibration acceleration (in broadband to $50 \mathrm{kHz}$ ) and to determine the nature of this relationship. The research was carried out on a set of 10 new tapered roller bearings type CBK-171.
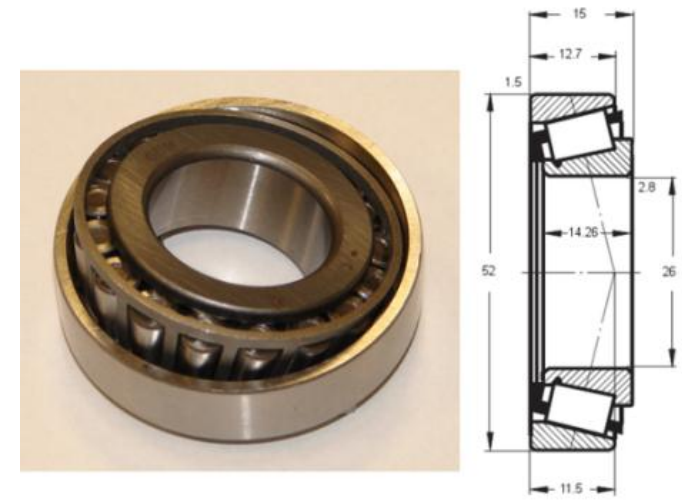

Fig. 1. Bearing type CBK 171, view and dimensions
During the 120 -second testing of the bearings, instantaneous rms and peak values of acceleration of vibrations generated by the bearings were determined. Vibrations generated by the bearings were recorded successively for different types of the lubricant used. Table 1 shows the designations and basic parameters of the lubricants used in the tests.

Table 1 Parameters of lubricants used in the tests (viscosity classification according to ISO [18])

\begin{tabular}{|c|c|c|c|}
\hline \multirow[t]{2}{*}{$\begin{array}{l}\text { Viscosity } \\
\text { class ISO }\end{array}$} & \multirow{2}{*}{$\begin{array}{c}\text { Average } \\
\text { kinematic } \\
\text { viscosity at } \\
40^{\circ} \mathrm{C},\left[\mathrm{mm}^{2} / \mathrm{s}\right]\end{array}$} & \multicolumn{2}{|c|}{$\begin{array}{c}\text { Kinematic viscosity } \\
\text { ranges at } 40^{\circ} \mathrm{C}, \\
{\left[\mathrm{mm}^{2} / \mathrm{s}\right]}\end{array}$} \\
\hline & & $\min$ & $\max$ \\
\hline ISO VG 3 & 3.2 & 2.88 & 3.52 \\
\hline ISO VG 7 & 6.8 & 6.12 & 7.48 \\
\hline ISO VG 12 & 12 & 10.8 & 13.2 \\
\hline ISO VG 22 & 22 & 19.8 & 24.2 \\
\hline ISO VG 32 & 32 & 28.8 & 35.2 \\
\hline ISO VG 46 & 46 & 41.4 & 50.6 \\
\hline ISO VG 68 & 68 & 61.2 & 74.8 \\
\hline ISO VG 100 & 100 & 90.0 & 110 \\
\hline ISO VG 150 & 150 & 135 & 165 \\
\hline ISO VG 220 & 220 & 198 & 242 \\
\hline ISO VG 320 & 320 & 288 & 352 \\
\hline ISO VG 460 & 460 & 414 & 506 \\
\hline
\end{tabular}

The tests were performed on a research stand, which enabled experiments to be carried out with fixed working parameters. The bearing loads: $30 \mathrm{~N}$ radial and $55 \mathrm{~N}$ axial (spring washer) were used to compensate the clearance. The rotational speed of the shaft and bearing inner ring was $1450 \mathrm{rpm}$.

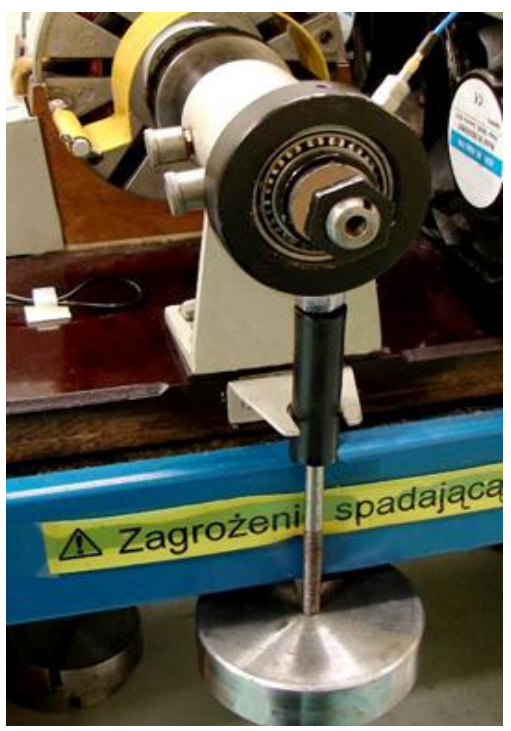

Fig. 2. Bearing housing with the bearing, vibration acceleration transducer and working load setting system (part of the test stand)

Vibration acceleration was recorded in the frequency band up to approx. $50 \mathrm{kHz}$. Within each of the 120 tests carried out (12 oils with different viscosities and 10 bearings), a 120-second signal sequence was recorded and analyzed each time (the first 120 seconds after start-up). To record 
vibrations, an accelerometer $\mathrm{ICP}^{\circledR}$ model M352A60 (PCB) mounted on a bearing housing, ensuring linear processing of vibrations in the frequency band under consideration was used.

Data acquisition module VibDAQ 4+ (24 bits, sampling frequency $97.66 \mathrm{kHz}$ ) was used for analogue-to-digital conversion of vibration and tachometric signals. Digital signal processing of the recorded data was carried out using a dedicated application developed in the DASYLab ${ }^{\circledR}$ (Data Acquisition System Laboratory) environment.

Earlier studies by the authors [19] have shown that the quality of research results in the scope under consideration is influenced by the proper preparation of bearings for testing and the method of supplying the bearing with the lubricant. With this in mind, the bearings were subjected to a careful preparation procedure prior to each test. It consisted in cleaning bearings in an ultrasonic washer in kerosene (3 min) and rinsing them in benzine. The cleaning procedure was repeated twice. Oils $(1 / 4 \mathrm{ml})$ were dosed precisely with a syringe (Fig. 3) to the bearing mounted on the stand. Before starting the test, the oil was distributed by turning the shaft several times by hand.

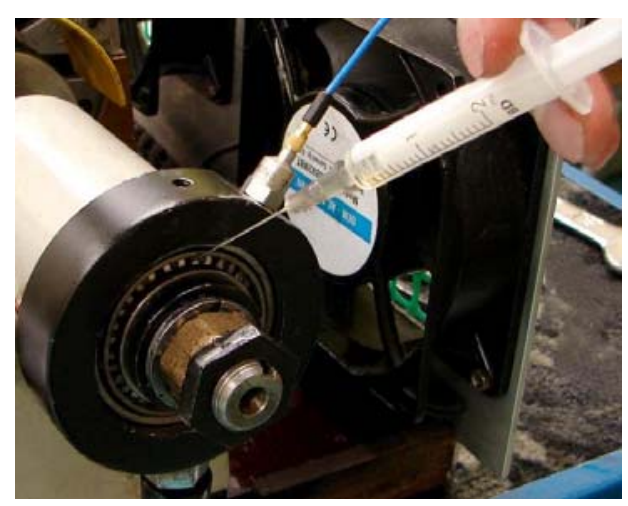

Fig. 3. Method of supplying lubricant to bearings

The basis for determining the influence of a lubricant on bearing vibrations were measures obtained as a result of parameterization of vibration acceleration signals determined in the band from $20 \mathrm{~Hz}$ to $50 \mathrm{kHz}$. Broadband measurements were aimed at covering the vast majority of VA phenomena occurring during testing of bearings. In order to obtain information about the stationarity of the testing process in terms of amplitude and lubricant influence the short-time processing of vibration acceleration signal was applied. As part of it, the characteristics describing the changes in the instantaneous rms values $a_{\mathrm{IRMS}}(j)$ and peak values $a_{\text {IPEAK }}(j)$ during the test (where $j$ is the successive number of the short-time sequence being processed) were determined. The rationale for such an analysis and determination of characteristics was as follows: - investigation of the extent to which the kinematic viscosity of oils affects the transition processes in the initial phase of the test, mainly related to the distribution of lubricant and stabilization of operating conditions,

- determination of the duration of the transition phase for individual lubricants followed by the stabilization of VA processes (it is expected to take place in the shortest possible time),

- assessment of the extent to which the lubricant used causes that the VA signal shows the characteristics of a quasi-stationary signal.

The proposed representative parameters: instantaneous rms values $a_{\text {IRMS }}$ and instantaneous peak values $a_{\text {IPEAK }}$ determined for the consecutive $j$-th short-time signal sequence (of about $0.084 \mathrm{~s}$ ) are defined as follows:

$$
\begin{aligned}
& a_{I R M S, j}=\left(\frac{1}{I} \sum_{i=1}^{I} a_{i j}^{2}\right)^{\frac{1}{2}}, \\
& a_{I P E A K, j}=\max _{i=1 \ldots I}\left\{a_{i j}\right\},
\end{aligned}
$$

where:

$i$ - successive number of the sample in the time window (short-time sequence of the signal),

$I=8192$, number of samples (size of the time window),

$j$ - the successive number of the processed signal sequence.

The instantaneous peak values of vibration accelerations should enable detection of phenomena mainly of impulse nature related to, among others, the following:

- movement of the cage and plays between it and the rolling elements [20], which may generate micro-impacts,

- instantaneous abrasions due to insufficient lubrication [4],

- presence of contamination [21],

- defects and damage to the raceways and rolling elements (e.g. scratches) occurring at the production stage.

One can suppose that an increase in the kinematic viscosity of the lubricant will have a significant impact on masking of the above mentioned phenomena and their visibility in the VA signal. Therefore, it will directly affect the value of $a_{\text {IPEAK }}$ as a measure sensitive to this type of phenomena.

The instantaneous rms value of vibration acceleration as an integral operator is less sensitive to pulse phenomena:

- carries information mainly about signal components (related to e.g. shape errors) and about random components (e.g. noise related to roughness of cooperating surfaces of rolling elements and raceways),

- represents the energy of all components of the VA signal (determined and random, including pulse ones) within each short-time sequence of the signal,

- can be used to determine the stationarity of the signal in amplitude terms, e.g. to determine after what time from the beginning of the test the 
signal acquires the characteristics of a quasistationary signal,

- the variability of the $a_{\text {IRMS }}$ value largely depends on the adopted averaging time (size of the short-time sequence).

The lubricant used will affect the $a_{\text {IRMS }}$ to varying degrees depending on its kinematic viscosity. It can be assumed that the decrease of this parameter due to the increased viscosity of the lubricant may indicate the intensification of shape error masking and the reduction of noise content in the VA signal, which is dependent on the surface condition. Then detection of such defects and estimation of the surface condition will become difficult or impossible.

An example of a short-time sequence of a vibration acceleration signal (approx. $0.084 \mathrm{~s}$ ) is shown in Figure 4a. It is worth noting that during this time the bearing inner ring (movable) performs more than 2 revolutions. This is indicated by the consecutive pulses of the tachometric probe (see Figure $4 \mathrm{~b}$ ). It follows that each sequence of signals will take into account the VA phenomena generated when rolling elements come into contact with the whole circumference of the raceway.

a)

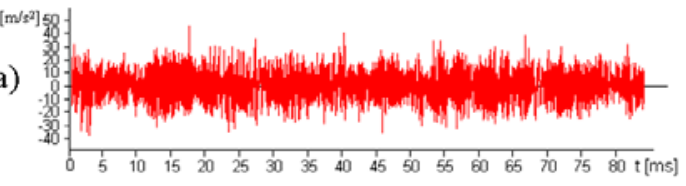

b)

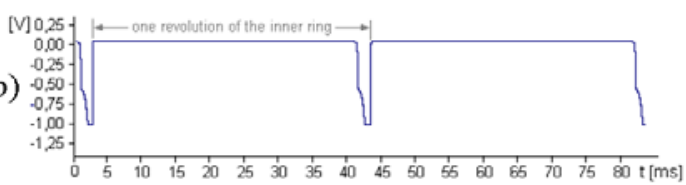

Fig. 4. Example of vibration acceleration signals (a) and from the tachometric probe (b) within one short-time sequence

Short-time sequencing of the signal was obtained as a result of its windowing by means of a rectangular window with a duration of $T=\Delta t \cdot I$ (where $\Delta t-$ sampling time, $I-$ number of signal samples in the sequence). The shift of the time window $\Delta \tau$ was equal to the size of the time window $T$, so there was no overlapping and no fragment of the recorded signal was omitted.

Figures $5 \mathrm{a}$ and $5 \mathrm{~b}$ show examples of discrete characteristics of changes of instantaneous $a_{\text {IRMS }}$ and $a_{\text {IPEAK }}$ values for the same bearing and lubricant type obtained for consecutive short time sequences $j(j=1 \ldots J$, where $J$ number of processed signal sequences). In order to better highlight the trend of changes, the characteristics $a_{\mathrm{IRMS}, k}(j)$ and $a_{\mathrm{IPEAK}, k}(j)$, were determined and averaged for $K=10$ bearings included in the test set. Characteristics $a_{\mathrm{IRMS}, k}(j)$ were averaged on a root mean square average and $a_{\mathrm{IPEAK}, k}(j)$ averaged on an arithmetic average basis according to the following formulae:

$$
\begin{aligned}
\bar{a}_{I R M S, j} & =\left[\frac{1}{I K} \sum_{k=1}^{K} \sum_{i=1}^{I} a_{i j k}^{2}\right]^{\frac{1}{2}}, \\
\bar{a}_{I P E A K, j} & =\frac{1}{K} \sum_{k=1}^{K} \max _{i=1 \ldots I}\left\{a_{i j k}\right\},
\end{aligned}
$$

where:

$k$ - consecutive number of the tested bearing, $K=10$, number of bearings in the test set,

$J=1430$, number of signal sequences processed in a 120 -second test.
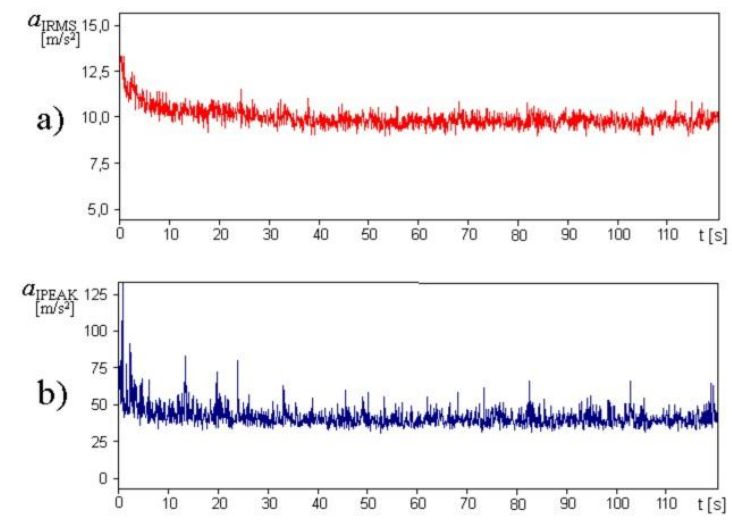

Fig. 5. Example of changes in instantaneous rms (a) and peak values (b) of vibration accelerations during a 120 -second test; characteristics obtained from 1430 sequences

As a result of the tests carried out, a set of characteristics $a_{I R M S, j, k}$ and $a_{I P E A K, j, k}$ was obtained. On their basis, the following measures of bearing vibration acceleration have been determined for each lubricant tested:

$\bar{a}_{\mathrm{RMS}}$ - the result of the root mean square averaging of the rms values obtained from the tests of a set of $K$ bearings; the averaged rms values were obtained from a signal covering the full duration of the test (120 s),

$$
\begin{gathered}
\bar{a}_{R M S}=\left[\frac{1}{J} \sum_{j=1}^{J}\left(\frac{1}{K} \sum_{k=1}^{K} a_{I R M S, j, k}^{2}\right)\right]^{\frac{1}{2}}= \\
=\left(\frac{1}{J} \sum_{j=1}^{J} \bar{a}_{I R M S, j}^{2}\right)^{\frac{1}{2}}
\end{gathered}
$$

$\overline{\hat{a}}_{\text {IRMS }}$ - the root mean square average of the maximum instantaneous rms values obtained when testing each bearing,

$$
\overline{\hat{a}}_{I R M S}=\left[\frac{1}{K} \sum_{k=1}^{K}\left(\max _{j=1 \ldots J}\left\{a_{I R M S, j, k}\right\}\right)^{2}\right]^{\frac{1}{2}},
$$

$\overline{\check{a}}_{\text {IRMS }}$ - the root mean square average of the minimum instantaneous rms values obtained when testing each bearing,

$$
\overline{\check{a}}_{I R M S}=\left[\frac{1}{K} \sum_{k=1}^{K}\left(\min _{j=1 \ldots J}\left\{a_{I R M S, j, k}\right\}\right)^{2}\right]^{\frac{1}{2}},
$$


$\bar{a}_{\text {IPEAK }}$ - averaged instantaneous peak values described by characteristics $a_{\mathrm{IPEAK}}(j)$ determined for the tested $K$-bearing set,

$\bar{a}_{I P E A K}=\frac{1}{J K} \sum_{k=1}^{K} \sum_{j=1}^{J} a_{I P E A K, j, k}=\frac{1}{J} \sum_{j=1}^{J} \bar{a}_{I P E A K, j}$,

$\bar{a}_{\text {PEAK }}$ - the arithmetic mean of the peak values obtained from the tests of a set of $K$ bearings; the peak values were obtained in this case from a signal covering the duration of the test (120 s),

$$
\overline{\hat{a}}_{I P E A K}=\frac{1}{K} \sum_{k=1}^{K} \max _{j=1 \ldots J}\left\{a_{I P E A K, j, k}\right\}=\bar{a}_{P E A K},
$$

$\overline{\check{a}}_{\text {IPEAK }}$ - the arithmetic mean of the lowest instantaneous peak values obtained when testing each bearing,

$$
\overline{\check{a}}_{I P E A K}=\frac{1}{K} \sum_{k=1}^{K} \min _{j=1 \ldots J}\left\{a_{I P E A K, j, k}\right\} .
$$

The aim of the multi-variant parameterization of vibration acceleration signals was to determine for which measure the test results - obtained through short-time processing (formulae 6, 7, 8 and 10) or for the entire 120-second test (formulas 5 and 9) can be better approximated with a modelling function. It will allow to determine the nature of the relation between the kinematic viscosity of the lubricant and the level of bearing vibrations, thus indirectly the masking bearing defects and damages in the VA signal.

\section{INFLUENCE OF OIL KINEMATIC VISCOSITY ON THE VALUES OF AMPLITUDE MEASURES}

Figure 6 shows averaged (for 10 bearings) characteristics showing changes in instantaneous values of vibration acceleration $\bar{a}_{\mathrm{IRMS}, j}$ (3) for the 12 lubricants used with kinematic viscosity from 3 to
$460 \mathrm{~mm}^{2} / \mathrm{s}$ and designations from ISO VG 3 to ISO VG 460 (see Table 1).

Analogous characteristics of $\bar{a}_{\mathrm{IPEAK}, j}$ for the oils tested turned out to be illegible, so their graphical form has not been included here. However, these data have been further parameterized.

Observation of changes in the instantaneous values of the rms values of vibration acceleration $\bar{a}_{\text {IRMS }}$ (see Fig. 6.) allows us to state that the level of bearing vibrations significantly depends on the viscosity of the lubricant. It can be seen that with increasing viscosity the characteristics $\bar{a}_{\text {IRMS }}(j)$ are located lower and lower (decrease in vibration level).

Moreover, different trends of changes in the $\bar{a}_{\text {IRMS }}$ parameter can be observed.

- decreasing trend for oils with the lowest viscosity ( 3 and $7 \mathrm{~mm}^{2} / \mathrm{s}$ ). It can be assumed that this is related to the process of lubricant distribution in the initial phase of the test [22] and the stabilization of operating conditions; it can be estimated that for ISO VG 3 oil such stabilization only takes place after 40 seconds.

- $\quad$ slightly increasing trend for oils with a higher viscosity (from 150 to $460 \mathrm{~mm}^{2} / \mathrm{s}$ ). Parallel studies conducted by the authors give reasons to state that during the 120 -second test the bearing oil temperature increases in the contact zone of rolling elements and raceway by $10-15^{\circ} \mathrm{C}$. The same increase in temperature was reported by Zhou et al. [13]. It is also known that an increase in oil temperature lowers its viscosity $[3,23]$.

- linear trend of almost constant value for oils with viscosity range from 12 to $100 \mathrm{~mm}^{2} / \mathrm{s}$; which means that the acceleration parameterization results do not change significantly during the entire 120 -second test, oils with such viscosities can be used for post-production testing of bearings.

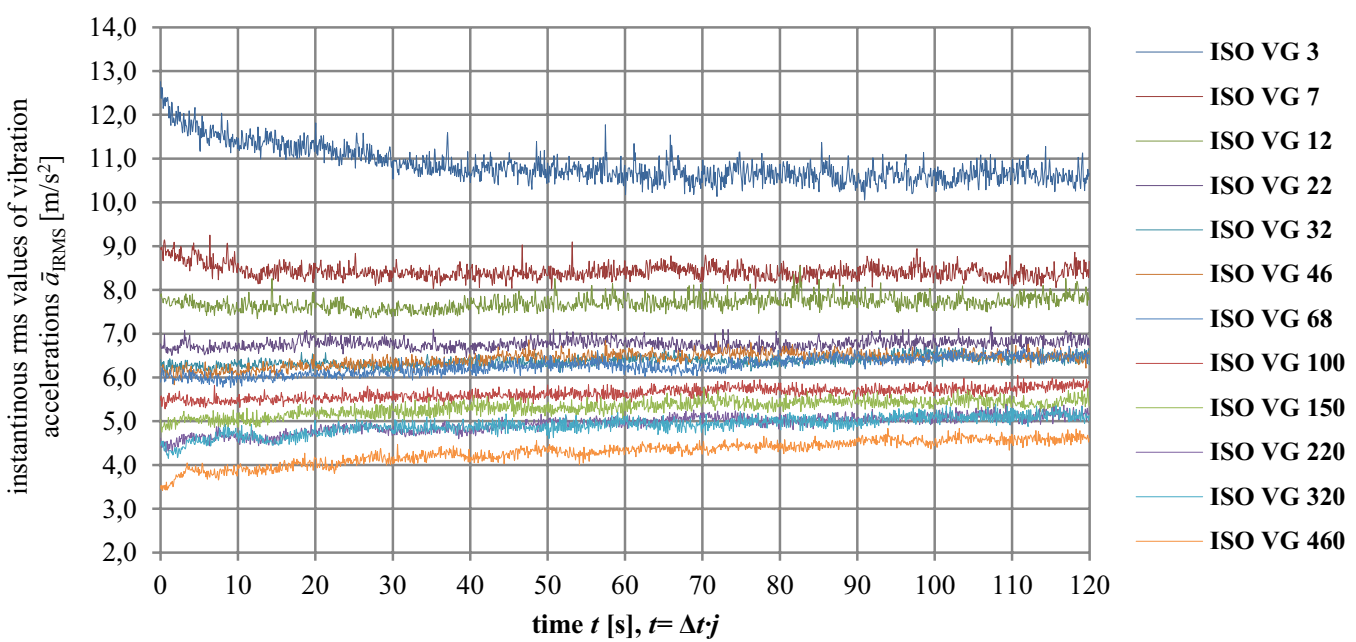

Fig. 6. Changes in instantaneous rms values of vibration accelerations of bearings (occurring during $120 \mathrm{~s}$ of the test) lubricated with oils of different kinematic viscosity (average values from a set of 10 new bearings) 
On the basis of the analysis of the stationary signal, the minimum duration of the post-production test (averaging time or the number of averaged short-time sequences) that gives a result with the required measurement uncertainty should be determined.

The analysis of trends in changes in the $\bar{a}_{\text {IPEAK }}$ parameter for the considered oils showed that they are similar to trends in $\bar{a}_{\text {IRMS }}$ changes, however, the deviation of values around the trend line is much larger.

Figure 7 provides a synthesis of test results. It shows the dependence of measures of rms values of vibration accelerations: $\bar{a}_{\text {RMS }}$, $\overline{\hat{a}}_{\text {IRMS }}$ and $\bar{a}_{\text {IRMS }}$ described by formulae $(5,6$ and 7$)$ on the viscosity of the lubricant. The figure is complemented by functions interpolating the results. The best adjustment to the measurement results was demonstrated by power functions. The value of the determination coefficient $\mathrm{R}^{2}$ at the level above 0.9 proves that the model curve was well matched to the test results. It can be seen that increasing the viscosity of the oil from 3 to $100 \mathrm{~mm}^{2} / \mathrm{s}$ causes almost twofold decrease in values of these parameters.

It is worth mentioning that the measures used for the parameterization of vibration acceleration have specific detection properties.

- The measure $\bar{a}_{\mathrm{RMS}}$ is determined for an averaging time equal to the duration of the test. Therefore, it covers all phenomena occurring during the test, both stationary and transient, related to the stabilization of working conditions (frictional and thermal).

- To determine the measure $\overline{\hat{a}}_{\text {IRMS }}$ proposed by the authors, the signal sequences in which the VA signal energy, for each of the tested bearings, was the highest, are taken into account. High signal energy within the given sequence can be associated with short-time phenomena, e.g. of an impact nature.

- Another measure defined in the paper, $\overline{\check{a}}_{\text {IRMS }}$, takes into account the most advantageous moment (signal sequence) of the test. For low viscosity oils, signal sequences are preferred in which the final testing phase when bearing lubrication conditions are stabilized (see Fig. 5, ISO VG 3). For oils with viscosity above 100 $\mathrm{mm}^{2} / \mathrm{s}$ signal sequences are taken into account in the initial phase of the test, in which the thermal phenomena do not have a significant effect (see ISO VG 460 in Fig. 5.). To determine the value of this measure, those signal sequences are taken into account, where the energy contribution of impulse events will not be significant. Therefore, this measure will well reflect other signal components, such as mono-/poly-harmonic and/or random noise signals, from which it is possible to detect shape errors and/or estimate the condition of the raceway surface and rolling elements.

The rms averaged $\bar{a}_{\mathrm{RMS}}$ values and standard deviations $\sigma$ obtained from the tests of a set of $K$ bearings (Table 2) allow to properly assess the influence of lubricant viscosity on bearing vibrations and to estimate the stability of the testing process. The data from the initial 120 seconds after the start of each test were used for this assessment. Normalization of standard deviations to mean values $\sigma / \bar{a}_{\mathrm{RMS}}$ can be the basis for estimating the influence of oil viscosity on the stationarity of the VA signal during bearing testing. This is illustrated in Fig. 8. It should be added that $\sigma / \bar{a}_{\mathrm{RMS}}$ takes into account both the variability of instantaneous rms values and the trend of these changes.

The following conclusions can be drawn from the graph in Figure 8 and Table 2:

- the highest stability of the testing process was obtained using oils with viscosities of 22 and $32 \mathrm{~mm}^{2} / \mathrm{s}$,

- high value of $\sigma / \bar{a}_{\mathrm{RMS}}$ obtained for the ISO VG 3 oil is caused by the decreasing trend of $\bar{a}_{\text {IRMS }}$ in the initial phase of the test resulting mainly from the stabilization of lubrication conditions in the bearing (see Fig. 5), to a lesser degree it is influenced by the variance of $\bar{a}_{\text {IRMS }}$ with respect to the trend line,

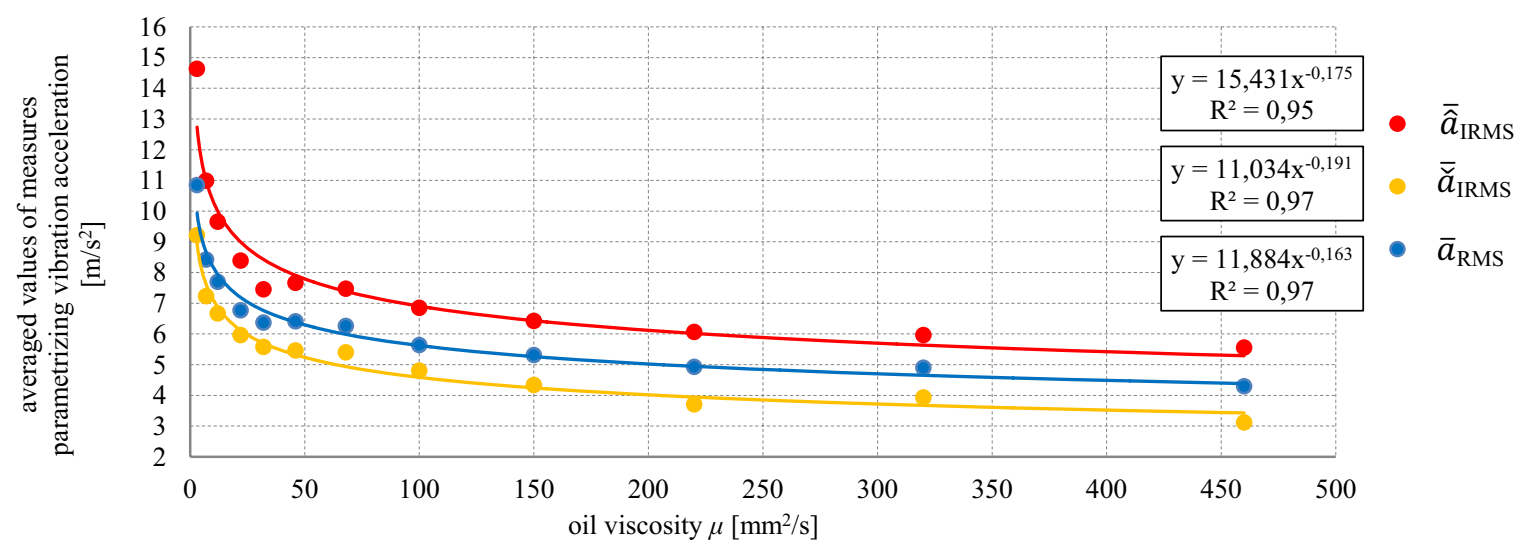

Fig. 7. Dependence of parameterization measures of rms values of bearing accelerations on oil kinematic viscosity and functions interpolating this dependence 
- high value of $\sigma / \bar{a}_{\mathrm{RMS}}$ obtained for oils with densities above $100 \mathrm{~mm}^{2} / \mathrm{s}$ is related to the growing trend of $\bar{a}_{\text {IRMS }}$ as a result of thermal processes; the increase in vibration level results from the decrease in oil viscosity with the increase in temperature during the test.

Table 2. Dependence of the averaged rms values of vibration accelerations $\bar{a}_{\mathrm{RMS}}$ on kinematic viscosity of oil

\begin{tabular}{|c|c|c|c|c|c|c|}
\hline \multirow{2}{*}{} & \multicolumn{6}{|c|}{ Oil kinematic viscosity according to ISO VG } \\
\cline { 2 - 7 }$\left[\mathrm{mm}^{2} / \mathrm{s}\right]$ \\
\hline $\begin{array}{c}\bar{a}_{\mathrm{RMS}} \\
{\left[\mathrm{m} / \mathrm{s}^{2}\right]}\end{array}$ & 10,86 & 8,42 & 7,70 & 6,77 & 6,37 & 6,41 \\
\hline $\begin{array}{c}\sigma \\
{\left[\mathrm{m} / \mathrm{s}^{2}\right]}\end{array}$ & 0,41 & 0,17 & 0,15 & 0,11 & 0,11 & 0,16 \\
\hline$\sigma / \bar{a}_{\mathrm{RMS}}$ & $3,74 \%$ & $1,98 \%$ & $1,97 \%$ & $1,58 \%$ & $1,74 \%$ & $2,46 \%$ \\
\hline
\end{tabular}

\begin{tabular}{|c|c|c|c|c|c|c|}
\hline \multirow{2}{*}{} & \multicolumn{6}{|c|}{ Oil kinematic viscosity according to ISO VG } \\
\cline { 2 - 7 } & 69 & 100 & 150 & 220 & 320 & 460 \\
\hline $\begin{array}{c}\left.\bar{a}_{\text {RMS }} / \mathrm{s}\right] \\
{\left[\mathrm{m} / \mathrm{s}^{2}\right]}\end{array}$ & 6,27 & 5,64 & 5,32 & 4,93 & 4,90 & 4,29 \\
\hline $\begin{array}{c}\sigma \\
{\left[\mathrm{m} / \mathrm{s}^{2}\right]}\end{array}$ & 0,19 & 0,13 & 0,17 & 0,19 & 0,20 & 0,26 \\
\hline$\sigma / \bar{a}_{\text {RMS }}$ & $2,99 \%$ & $2,29 \%$ & $3,27 \%$ & $3,92 \%$ & $4,14 \%$ & $6,16 \%$ \\
\hline
\end{tabular}

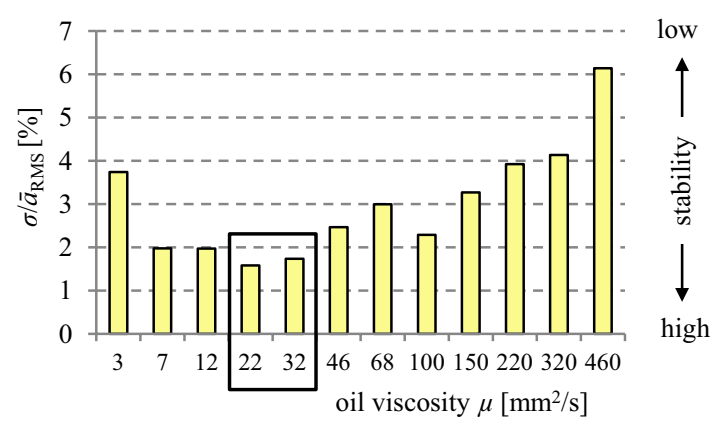

Fig. 8. Estimation of the influence of oil viscosity on the stability of the bearing testing process on the basis of parameter $\sigma / \bar{a}_{\mathrm{RMS}}$

Analogous analysis as for instantaneous rms values was carried out for instantaneous peak values determined by formulae 8 and 10 . The values of measures $\bar{a}_{\text {IPEAK }}$ and $\overline{\check{a}}_{\text {IPEAK }}$ as a function of oil viscosity are shown in Figure 9 . For the $\bar{a}_{\text {PEAK }}$ measure, the best approximation was obtained for the power function, but it was not satisfactory $\left(\mathrm{R}^{2}<0.65\right)$. Other modeling functions have shown an even smaller fit.

On the basis of Figure 9, a decrease in the values of measures parameterizing peak values $\left(\bar{a}_{\text {IPEAK }}\right.$ and $\left.\overline{\check{a}}_{\text {IPEAK }}\right)$ with an increase in kinematic viscosity of oil can be observed. A significant decrease was recorded in the viscosity range from 3 to $100 \mathrm{~mm}^{2} / \mathrm{s}$.

The measure $\overline{\check{a}}_{\text {IPEAK }}$ takes into account the sequence where the peak value was the lowest during the entire test. This means that this measure refers to the sequence in which the share of impulsive phenomena was the smallest. Therefore, it can be assumed that, like $\overline{\breve{a}}_{\text {IRMS }}$, this measure will well parameterize noise phenomena.

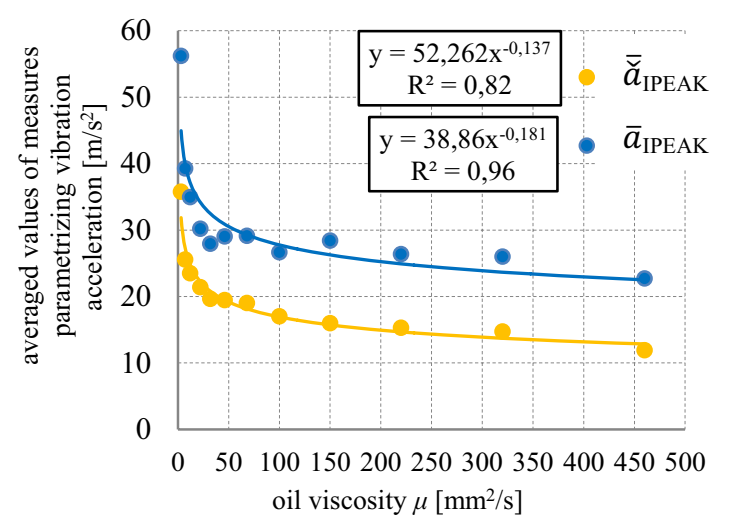

Fig. 9. Dependence of parameterization measures of peak values of bearing accelerations on oil kinematic viscosity and functions interpolating this dependence

On the other hand, the measure $\bar{a}_{\text {IPEAK }}$ determined on the basis of all signal sequences will well represent the average intensity of impulse phenomena in the whole testing process. This will allow to detect local damage such as scratches, micro-impacts, instantaneous abrasions or contamination.

A summary of parameters for peak values is given in Table 3.

Table 3. Dependence of the averaged peak values of vibration accelerations $\bar{a}_{\text {IPEAK }}$ on kinematic viscosity of oil

\begin{tabular}{|c|c|c|c|c|c|c|}
\hline \multirow{2}{*}{} & \multicolumn{5}{|c|}{ Oil kinematic viscosity according to ISO VG } \\
\cline { 2 - 7 } & 3 & 7 & 12 & 22 & 32 & 46 \\
\hline $\begin{array}{c}\bar{a}_{\text {IPEAK }} \\
{\left[\mathrm{m} / \mathrm{s}^{2}\right]}\end{array}$ & 56,22 & 39,28 & 34,95 & 30,19 & 27,95 & 29,05 \\
\hline$\sigma\left[\mathrm{m} / \mathrm{s}^{2}\right]$ & 4,45 & 2,89 & 2,16 & 1,77 & 1,55 & 1,85 \\
\hline$\sigma / \bar{a}_{\text {IPAEK }}$ & $7,91 \%$ & $7,36 \%$ & $6,17 \%$ & $5,86 \%$ & $5,54 \%$ & $6,36 \%$ \\
\hline
\end{tabular}

\begin{tabular}{|c|c|c|c|c|c|c|}
\hline \multirow{2}{*}{} & \multicolumn{6}{|c|}{ Oil kinematic viscosity according to ISO VG } \\
\cline { 2 - 7 } & 69 & 100 & 150 & 220 & 320 & 460 \\
\hline $\begin{array}{c}\left.\bar{a}_{\text {IPEAK }} / \mathrm{s}\right] \\
{\left[\mathrm{m} / \mathrm{s}^{2}\right]}\end{array}$ & 29,12 & 26,64 & 28,40 & 26,00 & 26,37 & 22,70 \\
\hline$\sigma\left[\mathrm{m} / \mathrm{s}^{2}\right]$ & 2,11 & 1,93 & 2,53 & 2,03 & 2,11 & 2,34 \\
\hline$\sigma / \bar{a}_{\text {IPEAK }}$ & $7,26 \%$ & $7,25 \%$ & $8,91 \%$ & $7,80 \%$ & $8,00 \%$ & $10,31 \%$ \\
\hline
\end{tabular}

The analysis of the data contained in Table 3 allows to draw similar conclusions as in the case of measures parametrizing rms values.

When selecting a lubricant for post-production testing of bearings, two criteria must be taken into account. In vibroacoustic testing procedures it is expected that there will be significant changes in the values of measures parameterizing vibration in case of defects/damage. The lubricant used should not mask these defects.

On the other hand, it is also important that the entire testing process is devoid of clear trends 
(influence of temperature and stabilization of lubrication conditions).

\section{MASKING OF DEFECTS AND DAMAGE}

With functions modelling the dependence of vibration parameterization measures on oil viscosity, it is possible to define indicators for estimating the intensity of masking bearing faults and defects in the vibration signal related to the change in oil viscosity: DMF-dimensionless Defect Masking Factor showing the multiplication of changes and DML - Defect Masking Level expressed in $\mathrm{dB}$,

$$
\begin{gathered}
D M F(\mu)=\frac{a_{X(r e f)}}{a_{X}(\mu)} \\
D M L(\mu)=20 \log _{10}\left(\frac{a_{X(r e f)}}{a_{X}(\mu)}\right),
\end{gathered}
$$

where for $a_{\mathrm{X}}$ are taken $\bar{a}_{\text {RMS }}, \overline{\hat{a}}_{\text {IRMS }}, \overline{\check{a}}_{\text {IRMS }}, \bar{a}_{\text {IPEAK }}$ and $\overline{\check{a}}_{\text {IPEAK }}$ respectively.

Figure 10 shows the $\operatorname{DML}(\mu)$ dependencies determined on the basis of the above mentioned modelling functions (see Fig. 7 and Fig. 9). The reference values for $a_{X(r e f)}$ were $a_{X(\mu=3)}$ (for oil with a kinematic viscosity of $\left.3 \mathrm{~mm}^{2} / \mathrm{s}\right) \operatorname{DML}(\mu)$ relationships were determined for all parameters for which the power model showed coefficient of determination $\mathrm{R}^{2}>0.8$.

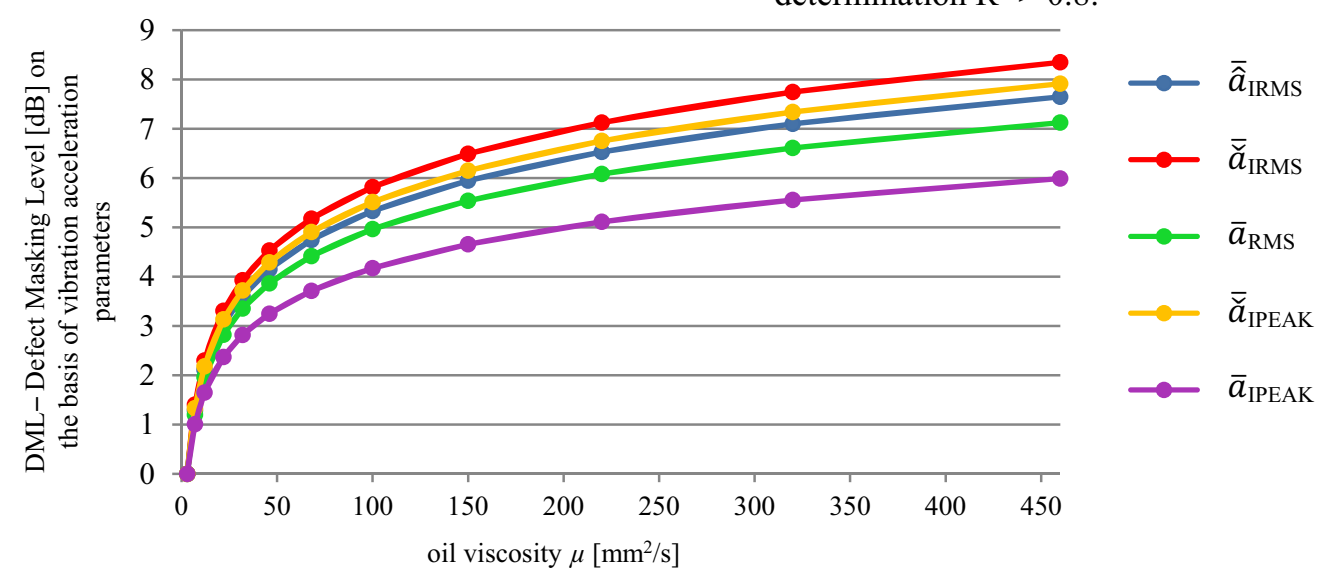

Fig. 10. Masking level of signal characteristics related to faults and defects in the vibration signal generated by the tested bearings as a function of oil kinematic viscosity

On the basis of Fig. 10 it can be clearly stated that the level of masking of defects increases with the increase in viscosity of the oil. Figure 11 shows the two extreme characteristics of $\operatorname{DML}(\mu)$. The upper one, determined on the basis of $\overline{\breve{a}}_{\text {IRMS }}$ is related to the masking of information about the surface condition (roughness) which is manifested by a reduction of noise level in the VA signal. The lower one, determined on the basis of $\bar{a}_{\text {IPEAK, is }}$ related to the masking of local (point) damage of raceways / rolling elements (decrease in peak values of impulses in the VA signal along with increase of oil viscosity).

With the data from Tables 2 and 3 and Figure 11 it is possible to determine what viscosity of oil will be optimal for the testing process. The oil used should guarantee both the stability of the testing process and a low level of defect masking. Based on the test results, it can be concluded that the oil viscosity should be in the range of $20-30 \mathrm{~mm}^{2} / \mathrm{s}$. The characteristics presented in Figure 11 can also be the basis for a more detailed analysis. For example, the use of ISO VG 22 oil instead of ISO VG 3 will increase the level of defect masking by an average of $2.9 \mathrm{~dB}$, but on the other hand it will guarantee better stability of the testing process. (see $\sigma / \bar{a}_{\text {RMS }}$ in Table 2 ). The use of higher viscosity oil, e.g. ISO VG 150 instead of ISO VG 22, will not be advisable. This will increase the level of defect masking by an average of $2.8 \mathrm{~dB}$ and lower process stability (the $\sigma / \bar{a}_{\mathrm{RMS}}$ parameter increases). This is related to the influence of thermal phenomena during the test.

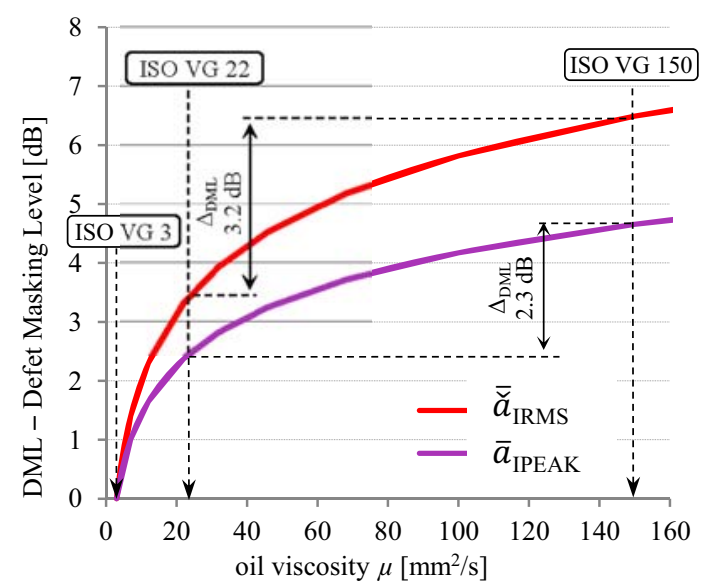

Fig. 11. Example of estimating of the increase in the level of masking of defects and faults in the

VA signal due to a change in the kinematic viscosity of the oil used in the process of post-production testing of bearings.

\section{CONCLUSIONS}

The conducted research allowed to state that the vibrations of rolling bearings depend on the viscosity of the lubricant used. An increase in 
viscosity results in a decrease in the values of the vibration acceleration parameterization measures in the aspect of broadband measurements.

The highest sensitivity to the change in the viscosity of the oil used was demonstrated by the averaged (for the set of test bearings) minimum instantaneous rms value $\overline{\check{a}}_{\text {IRMS }}$. It can be assumed that this measure, as an integrating operator, well reflects the presence of mono-/poly-harmonic and/or random noise components in the VA signal. In addition, $\bar{a}_{\text {IRMS }}$ shows little sensitivity to the presence of impulse phenomena.

On the other hand, the average instantaneous peak value $\bar{a}_{\text {IPEAK }}$ reacting to short-time impulse events in the signal shows the lowest sensitivity to changes in oil viscosity.

It follows from the above that the increase in viscosity of the lubricant used will mask the low-energy signal components related to the surface condition (roughness) and shape errors (waviness) to a greater extent than the local defects of the raceways and rolling elements.

The Defect Masking Level $\operatorname{DML}(\mu)$ indicator defined in the work may be useful for estimating the effect of oil viscosity on masking the defects of new bearings during their post-production testing.

The results of the conducted research confirmed the importance of the procedures for preparing bearings for the tests shown in previous works $[19,24]$.

Taking into account the criteria: stability of the testing process and low impact on masking of bearing defects, oils with viscosity in the $22-32 \mathrm{~mm}^{2} / \mathrm{s}$ range will be optimal for use in the post-production testing process.

\section{ACKNOWLEDGMENTS}

The authors thank Orlen Oil Sp. z o. o. for making samples available for testing.

The results presented are results of the research that was funded with grant $02 / 21 / \mathrm{DSMK} / 3501$ for education allocated by the Ministry of Science and Higher Education of the Republic of Poland.

\section{REFERENCES}

1. Hammami M, Martins R, Fernandes C, Seabra J, Abbes MS, Haddar M. Friction torque in rolling bearings lubricated with axle gear oils. Tribology International 2018; 119: 419-435. https://doi.org/10.1016/j.triboint.2017.11.018

2. Liu L, Yang C, Sheng Y. Wear model based on realtime surface roughness and its effect on lubrication regimes. Tribology International 2018; 126: 16-20. https://doi.org/10.1016/j.triboint.2018.05.010

3. Mullett G. Grease lubrication of rolling bearings. Tribology 1973; 6: 21-28.

4. FAG Kugelfischer Georg Schäfer AG. Rolling Bearing Lubrication. Publ. No. WL 81 115/4 EA

5. Żabicki D. Lubrication of gears and bearings, Smarowanie i Mechanizmy, addition to the magazine Główny Mechanik 2015; July-August: 30-32. Polish.
6. Balan MR, Tufescu A, Cretu SS. A case study on relation between roughness, lubrication and fatigue life of rolling bearings, Materials Science and Engineering 2016; 147: 1-12. https://doi.org/10.1088/1757-899X/147/1/012013

7. Jamadar I, Vakharia D. Correlation of base oil viscosity in the grease with vibration severity of damaged rolling bearings, Industrial Lubrication and Tribology 2018; 70(2): 264-272.

https://doi.org/10.1108/ILT-04-2016-0078

8. Randall R, Antoni J. Rolling element bearing diagnostics - A tutorial. Mechanical Systems and Signal Processing 2010; 25: 485-520. https://doi.org/10.1016/j.ymssp.2010.07.017

9. Randall R. Vibration-based Condition Monitoring: Industrial, Aerospace and Automotive Applications. New Delhi: Wiley; 2011: 67-71. https://doi.org/10.1002/9780470977668

10. ISO 15242-1(2015) Rolling bearings - Measuring methods for vibration - Part 1: Fundamentals

11. Ma F, Li Z, Qiu S, Wu B, An Q. Transient thermal analysis of grease-lubricated spherical roller bearings, Tribology International 2016; 93: 115-123. https://doi.org/10.1016/j.triboint.2015.09.004

12. Xu J, Zhang J, Huang Z, Wang L. Calculation and finite element analysis of the temperature field for high-speed rail bearing based on vibrational characteristics, Journal of Vibroengineering 2015; 17(2): 720-732.

13. Zhou X, Zhang $\mathrm{H}$, Hao $\mathrm{X}$, Liao $\mathrm{X}$, Hana Q. Investigation on thermal behavior and temperature distribution of bearing inner and outer rings, Tribology International 2019; 130: 289-298. https://doi.org/10.1016/j.triboint.2018.09.031

14. Takabi J, Khonsari MM. Experimental testing and thermal analysis of ball bearings, Tribology International 2013; 60: 93-103.

https://doi.org/10.1016/j.triboint.2012.10.009

15. Bakoglidis KD, Nedelcu I, Ivanov IG. Rolling performance of carbon nitride-coated bearing components in different lubrication regimes, Tribology International 2017; 114: 141-151. https://doi:10.1016/j.triboint.2017.04.006

16. Eder SJ, Ielchici C, Krenn S, Brandtner D. An experimental framework for determining wear in porous journal bearings operated in the mixed lubrication regime. Tribology International 2018; 123: 1-9. https://doi.org/10.1016/j.triboint.2018.02.026

17. Serrato R, Maru MM, Padovese LR. Effect of lubricant viscosity grade on mechanical vibration of roller bearings. Tribology International 2007; 40: 1270-1275. https://doi.org/10.1016/j.triboint.2007.01.025

18. ISO 3448:1992 Industrial liquid lubricants - ISO viscosity classification

19. Gałęzia A, Barczewski R, Jakubek B. Possibilities of Faults Detection of Rolling Bearings Using Energetic Descriptors of Vibrations Signals. In: Timofiejczuk A, Chaari F, Zimroz R, Bartelmus W, Haddar M, eds. Advances in Condition Monitoring of Machinery in Non-Stationary Operations. Springer; 2018. https://doi.org/10.1007/978-3-319-61927-9 31

20. Deng S, Gu J, Cui Y, Zhang W. Dynamic analysis of a tapered roller bearing. Industrial Lubrication and Tribology 2018; 70(1): 191-200. https://doi.org/10.1108/ILT-12-2016-0307

21. Maru MM., Serrato-Castillo R, Padovese LR. Influence of oil contamination on vibration and wear in ball and roller bearings. Industrial Lubrication and 
Tribology 2007; 59(3): 137-142.

https://doi.org/10.1108/00368790710746101

22. Gershuni L, Larson MG, Lugt PM. Lubricant replenishment in rolling bearing contacts. Tribology Transactions 2008; 51: 643-651.

https://doi.org/10.1080/10402000802192529

23. Ryniewicz AM, Bojko $Ł$, Madej T. Estimation of viscosity engine oils using rotational rheometer. Scientific Journal of Silesian University of Technology. Series Transport 2014; 83: 225-234. Polish.

24. Jakubek B, Barczewski R., Jakubowicz M. The influence of the lubrication on the vibroacoustic signal generated by rolling bearings. Journal of Vibrations in Physical Systems 2017; 28: 1-9.

Received 2018-08-31

Accepted 2018-12-14

Available online 2018-12-17

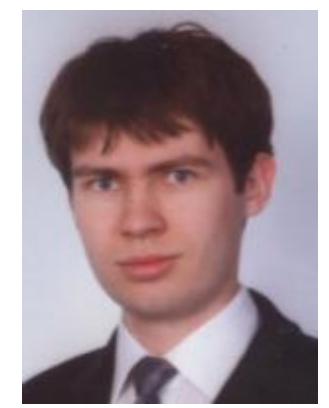

tapered roller bearings.

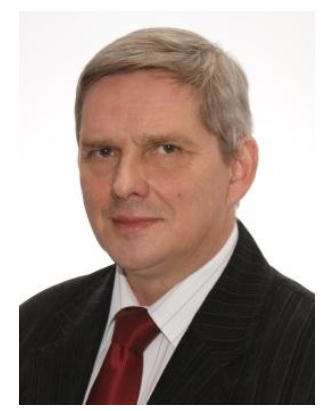

Bartosz JAKUBEK, M. Sc., is an assistant at the Institute of Applied Mechanics of Poznan University of Technology. His scientific interests include: diagnostics and vibroacoustics of machinery and devices as well as techniques and methods of digital signal processing. In particular, he deals with post-production diagnostics of

Roman BARCZEWSKI, PhD, is an assistant professor and head of the Systems Diagnostics Laboratory at the Institute of Applied Mechanics of Poznan University of Technology. Specialization: diagnostics and vibroacoustics of machines and environment, techniques and methods of digital signal processing, vibration and noise testing, diagnostic systems. VicePresident of the Polish Society of Technical Diagnostics. 